\title{
Dominance of Iminopeptidase Activity in the Human Oral Bacterium Treponema denticola ATCC 35405
}

\author{
Kauko K. Mäkinen, Salam A. Syed, Pirkko-Liisa Mäkinen, and Walter J. Loesche \\ School of Dentistry, University of Michigan, Ann Arbor, Michigan, USA
}

\begin{abstract}
Treponema denticola ATCC 35405, a human oral spirochete associated with periodontal disease, was shown to contain three enzymes (I, II, and III) with proline iminopeptidase activity. II and III were considered to be true iminopeptidases, whereas enzyme I was found to be a benzoylarginine peptidase with iminopeptidase activity. Enzyme III, the dominant proline iminopeptidase of $T$. denticola in terms of its activity toward $N$-L-prolyl-2-naphthylamine, was considered to be a sulfhydryl peptidase: $0.167 \mu M p$-chloromercuribenzoic acid totally inactivated the enzyme, and $1.0 \mathrm{~m} M$ dithiothreitol restored $92 \%$ of activity. The activity of this enzyme was not affected by metal chelators. Chemical modification of enzyme III suggests that tyrosyl (or histidyl) and carboxyl groups may be necessary for its activity. The hydrolysis of $\mathrm{N}$ L-prolyl-2-naphthylamine was found to be very characteristic of T. denticola ATCC 35405; out of 24 different $N$-L-aminoacyl-2-naphthylamines tested, only the proline derivative was hydrolyzed at a high rate. The substrate specificity of the enzymes discovered indicates that they may be important for the nutrition of $T$. denticola. The iminopeptidase activity may be related to the pathogenicity of this organism in periodontal disease.
\end{abstract}

Treponema denticola and other oral treponemes have been found to be associated with human periodontal disease [1,9-11]. Electron microscopic studies have shown the cells of $T$. denticola to adhere to human epithelial cells in vitro [21]. T. denticola does not use carbohydrates for energy, but grows well in various complex media supplemented with rabbit serum $[3,10]$. In the environment of gingival plaque, $T$. denticola has access to finite amounts of proteins, peptides, and amino acids. The specific nutritional requirements of this organism should be reflected in the number and types of intra- and extracellular enzymes elaborated by the cells, since such enzymes would be needed to make peptides or amino acids available for the growth of the cells. The possible significance of Treponema enzymes as potential virulence factors in the development of marginal periodontitis has been emphasized recently $[8,18,25]$. Considerable emphasis has been placed on treponemal peptidases; however, chemical information about $T$. denticola peptidases is virtually nonexisting. The first attempts to purify Treponema proteolytic enzymes were recently made [20, 24]. This report describes a procedure for partial purification and biochemical characteristics of three peptidases formed by $T$. denticola. These enzymes were discovered by using $N$-L-prolyl-2naphthylamine (pro-2NA) as substrate and were, therefore, tentatively designated as proline iminopeptidases.

\section{Materials and Methods}

Cultivation and treatment of the cells. Cells of $T$. denticola ATCC 35405 , originally isolated from human periodontal pockets [5], were grown aerobically for $48 \mathrm{~h}$ in 100-ml lots of tryptoneyeast extract-heart infusion broth containing $10 \%$ of heat-inactivated rabbit serum (but no agar, gelatin, or fatty acids) [20]. The $100 \mathrm{ml}$ growth medium consisted of $90 \mathrm{ml}$ of the broth kept for at least 10 days in an aerobic incubator and $10 \mathrm{ml}$ of the seed culture in the above medium. The cultures were performed in capped 250-ml flasks. The purity of the cells was checked by phase contrast microscopy. The cells were harvested and sonicated as before [18]. The sonicates were centrifuged for $10 \mathrm{~min}$ at $4500 \mathrm{~g}$. The supernatant fluids obtained after sonication were used as starting material in the purification of the iminopeptidases.

Enzyme determinations. Iminopeptidase activity was assayed as previously described using pro-2NA as substrate [15]. The compounds tested as substrates and the respective methods were as follows: 24 different $N$-aminoacyl-2-naphthylamines (NA) [15], 


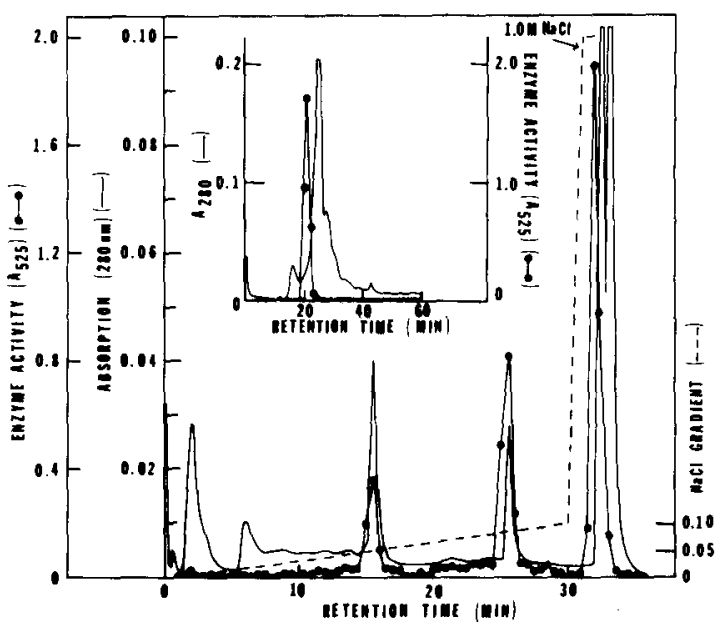

Fig. 1. Purification of iminopeptidases I, II, and III from the cells of Treponema denticola ATCC 35405. (Inset) FPLC of a concentrated cell sonicate on a Superose gel column. The elution buffer was $50 \mathrm{~m} M$ Tris- $\mathrm{HCl}$, pH 7.0 , containing $1 \mathrm{~m} M \mathrm{CaCl}_{2}$ and $50 \mathrm{~m} M \mathrm{NaCl}$. The active fractions (19-22 $\mathrm{min})$ were pooled, concentrated, and applied on the Mono $Q$ anion exchange column. The elution buffer was $10 \mathrm{~m} \mathrm{M}$ Tris- $\mathrm{HCl}, \mathrm{pH} 7.0$ (containing $0.1 \mathrm{~m} \mathrm{M} \mathrm{CaCl}$ and, up to $31 \mathrm{~min}$, a liner $\mathrm{NaCl}$ gradient from 0 to $0.1 \mathrm{M}$; the $\mathrm{NaCl}$ concentration was thereafter increased to $1.0 \mathrm{M}$ ). The enzymes eluted from the column were designated as I (16 $\mathrm{min})$, II (26 $\mathrm{min})$, and III (32 $\mathrm{min})$, respectively.

$N \alpha$-benzoyl-DL-arginyl-p-nitroaniline (BAPNA) [7, 14], phenylazobenzyloxycarbonyl-L-prolyl-leucylglycyl- L - prolyl-D - arginine (a collagenase substrate) [26], azocoll [4, 19], azocasein [23], elastin-orcein [22], and bovine serum albumin [6]. These substrates were obtained from Sigma Chemical Company (St. Louis, Missouri). Protein was determined by the Bio-Rad protein assay method [2].

Fast protein liquid chromatography (FPLC) and electrophoresis. All chromatographic separations were carried out on a complete Pharmacia FPLC system (Uppsala, Sweden) as previously described [18]. A Superose-6 gel column was used in the determination of the molecular weight of the enzymes. Sodium dodecyl sulfate polyacrylamide gel electrophoresis (SDS-PAGE) was performed as previously described [20].

Partial purification of proline iminopeptidases. The supernatant fluids of the cell sonicates resulting from the $100-\mathrm{ml}$ cultivations were concentrated from $10 \mathrm{ml}$ to $1 \mathrm{ml}$ using Amicon Centriflo CF25 membrane cones (cutoff $25,000 \mathrm{~mol} \mathrm{wt}$; Amicon, Lexington, Massachusetts). The $1-\mathrm{ml}$ concentrates were treated with $0.2 \mu$ ACRO LC13 filters (Gelman Sciences, Ann Arbor, Michigan) and chromatographed in $0.4-\mathrm{ml}$ portions on the Superose column. One major enzyme with iminopeptidase activity appeared in the chromatograms. The most active fractions of each separation were pooled $(3 \mathrm{ml})$ and concentrated to $0.5 \mathrm{ml}$ with Amicon Centricon-30 Microconcentrators (cufoff $30,000 \mathrm{~mol}$ wt). The concentrates were injected into the anion exchange column of the FPLC system. The enzyme obtained from the gel column yielded three enzymes with iminopeptidase activity. These enzymes were designated as I, II, and III, in the order of elution from the column with the $\mathrm{NaCl}$ gradient shown (Fig. 1). Because of loss of activity, enzymes I and II were not purified further, but enzyme III, eluted from the column with $1.0 \mathrm{M}$ $\mathrm{NaCl}$, was further purified by hydrophobic interaction chromatography on a phenyl-Sepharose CL-48 column $(0.7 \mathrm{~cm} \times 10$ $\mathrm{cm}$; elution with $10 \mathrm{~m} M$ Tris- $\mathrm{HCl}$ buffer, $\mathrm{pH}$ 7.0). The enzyme, applied on the column in the form of $30 \%\left(\mathrm{NH}_{4}\right)_{2} \mathrm{SO}_{4}$ solution, was bound to the gel and finally desorbed with the above buffer containing 50\% ethylene glycol. Ethylene glycol and excess salt were removed by dialysis, and the resulting enzyme was subjected to characterization studies. The purification of enzyme III was repeated four times starting from $100-\mathrm{ml}$ cultures.

Chemical modification of enzyme III. Diazotized sulfanilic acid (DSA), diethylpyrocarbonate (DEP), tetranitromethane (TNM), and 1-(ethoxycarbonyl)-2-ethoxy-1,2-dihydroquinoline (EEDQ) were used in chemical modification studies as described previously $[13,16,17]$. The modifications were performed at $+4^{\circ} \mathrm{C}$, except in the case of EEDQ, which was tested at $+40^{\circ} \mathrm{C}$ [13]. Stability controls without the modifiers were included [16], and the effect of the modifiers on the enzyme assay methods themselves was considered.

Kinetic studies. Plots of $1 / v$ versus $1 /[S],[S] / v$ versus $v$, and $v /[S]$ versus $v$, where $[S]$ is the substrate concentration and $v$ is the initial velocity, were used to calculate the $K_{m}$ value of proline iminopeptidase III.

\section{Results}

Specific activity of Treponema denticola sonicates. The sonicates of $T$. denticola exhibited remarkably narrow substrate specificity toward $N$-aminoacyl-2naphthylamines. The only substrate that was hydrolyzed at a considerable rate under these conditions was pro-2NA (Table 1). These results suggest that the hydrolysis of pro-2NA is very characteristic of T. denticola ATCC 35405.

Purification of iminopeptidases. Figure 1 shows the separation of the iminopeptidases on the gel and anion exchange columns. FPLC on the gel column normally yielded one major enzyme peak with iminopeptidase activity, while the subsequent anion exchange separation of this peak produced three major enzymes. Enzymes I and II coincided with symmetric protein peaks. Attempts to purify these enzymes further were not successful as a result of their low activity. Enzymes I and II, obtained after FPLC on the Mono Q column, and enzyme III, obtained after the hydrophobic interaction chromatography, were all homogeneous in rechromatography on the gel and anion exchange columns, with the protein peaks (determined at $214 \mathrm{~nm}$ ) coinciding 
with enzyme activity peaks. Enzyme III was obtained in sufficient amounts for SDS-PAGE, where one protein band coinciding with iminopeptidase activity was detected. The molecular weight of the dominant enzyme III was 100,000. Enzymes I and Il occurred in smaller and varying amounts. The increase in the specific activities of enzyme III during purification is shown in Table 2 .

Substrate specificity. All three enzymes displayed narrow substrate specificity with regard to the amino acid 2NAs tested. Enzymes II and III hydrolyzed pro-2NA at a high rate and were thus considered true proline iminopeptidases. Enzymes II and III hydrolyzed BANA and BAPNA at equal, low rates and had no detectable activity toward the pentapeptide collagenase substrate, nor did enzymes II and III hydrolyze the other proteinase substrates mentioned above. Introduction of an $\mathrm{OH}$ group to the pyrrolidine ring (for hydroxyproline) decreased the rate of the hydrolysis significantly. Enzyme I hydrolyzed BANA (Table 3), BAPNA, azocasein, and the collagenase substrate at clearly measurable rates, and azocoll, serum albumin, and elastin-orcein at a very low rate. This enzyme may be an endopeptidase with iminopeptidase and benzoylarginine peptidase activity.

Effect of $\mathrm{pH}$ on the rate of hydrolysis. The $\mathrm{pH}$ optimum for enzyme III was 7.0-7.5, whereas for enzymes I and II a broader optimum between $\mathrm{pH} 7$ and 8 was obtained (Fig. 2). Tris- $\mathrm{HCl}$ buffer consistently yielded higher activity than did phosphate buffer. No iminopeptidase activity was observed at $\mathrm{pH}$ values below 5 .

Effect of chelators and other reagents on enzyme III. E.DTA, 1,10-phenantroline, and 8-hydroxyquinoline 5-sulfonic acid (metal chelators), tested at 0.0167-0.00167 $\mathrm{mM}\left(10^{4}-10^{5} \times\right.$ molar excess with respect to enzyme), had no effect on the rate of hydrolysis of pro-2NA. 0.167-0.0167 $\mathrm{mM}$ phenylmethylsulfonyl fluoride, a reagent that has been used to probe active serine residues in enzymes, caused a $25-27 \%$ inhibition, whereas dithiothreitol (DTT) at these same concentrations had no effect. $p$-Chloromercuribenzoic acid ( $\mathrm{pCMB}$ ) was a potent inhibitor of the enzyme: $1.67 \mu M$ reagent caused $100 \%$ inhibition in $10 \mathrm{~m} M$ Tris- $\mathrm{HCl}, \mathrm{pH} 7.0$. Under the same conditions, $0.16 \mu M$ and $0.0167 \mu M$ inhibitor caused $90 \%$ and $85 \%$ inhibition, respectively. Addition of $1.0 \mathrm{~m} M$ DTT to a reaction mixture containing 1.67 $\mu M$ pCMB (no enzyme activity detect-
Table 1. Substrate specificity of the cell sonicate of Treponema denticola ATCC $35405^{a}$

\begin{tabular}{lc}
\hline Substrate & $\begin{array}{c}\text { Specific activity } \\
\text { (nmol } \mathrm{min}^{-1} \mathbf{m g}^{-1} \text { ) }\end{array}$ \\
\hline L-Alanyl-2NA & 0.30 \\
L- $\alpha$-Aspartyl-2NA & 0.96 \\
L-Arginyl-2NA & 0.37 \\
$\alpha$-Benzoyl-L-arginyl-2NA (BANA) & 1.32 \\
L-Cystinyl-2NA & 0.3 \\
L- $\alpha$-Glutamyl-2NA & 0.18 \\
L- $\gamma$-Glutamyl-2NA & 0.71 \\
Glycyl-2NA & 0.03 \\
Glycylprolyl-2NA & 0.07 \\
Glycylglycyl-2NA & 0.01 \\
L-Histidyl-2NA & 0.15 \\
L-Hydroxyprolyl-2NA & 0.18 \\
L-Isoleucyl-2NA & 0.19 \\
L-Leucyl-2NA & $<0.01$ \\
L-Leucylglycyl-2NA & 0.05 \\
L-Lysyl-2NA & 0.07 \\
L-Methionyl-2NA & 0.12 \\
L-Prolyl-2NA (pro-2NA) & 16.90 \\
L-Pyrrolidonyl-2NA & 0.38 \\
L-Seryl-2NA & 0.02 \\
L-Threonyl-2NA & 0.09 \\
L-Tyrosyl-2NA & 0.09 \\
L-Tryptophyl-2NA & 0.12 \\
L-Valyl-2NA & 0.14 \\
\hline
\end{tabular}

\footnotetext{
a Tested in $0.1 M$ Tris-HCl buffer, $\mathrm{pH} 7.5$. Substrate concentrations: $0.167 \mathrm{mM}$. The arithmetic means of three determinations are indicated. The sonicates were concentrated tenfold for this experiment with Amicon Centriflo CF25 membrane cones.
}

able) restored $92 \%$ of activity. These results suggest that the activity of enzyme III may depend on SHgroups.

Chemical modification of enzyme III. Modification of enzyme III with DEP, DSA, TNM, and EEDQ was performed with several modifier concentrations, modification times, and buffers. The results are summarized as follows: Two consecutive additions of DEP (at 0 and $30 \mathrm{~min}$; initial concentration in both cases, $1.0 \mathrm{~m} M$ ) in $10 \mathrm{~m} M$ Tris- $\mathrm{HCl}(\mathrm{pH} \mathrm{7.0)}$ caused in 60 min a total inactivation of the enzyme. DSA was tested in the above buffer containing $\mathrm{Na}_{2} \mathrm{CO}_{3}$ (final $\mathrm{pH}$ 9.5-10.4). The diazotization was initiated by adding a 50-nmol portion of the reagent and thereafter continued at 10 -min intervals by adding similar portions of the reagent [16]. After 2-3 additions, the enzyme lost more than $90 \%$ of its activity. TNM also caused a rapid inactivation of enzyme III; $1.0 \mathrm{~m} M$ reagent abolished all enzyme activity in $60 \mathrm{~min}$. The sensitivity of enzyme III to DSA and TNM may result from the importance of 
Table 2. Purification of proline iminopeptidase III from the cells of Treponema denticola ATCC 35405

\begin{tabular}{lccc}
\hline Purification step & $\begin{array}{c}\text { Total protein } \\
\text { content (mg) }\end{array}$ & $\begin{array}{c}\text { Specific activity } \\
\left(\mu \text { mol min }^{-1} \text { mg }^{-1}\right)^{\alpha}\end{array}$ & $\begin{array}{c}\text { Recovery of } \\
\text { original enzyme } \\
\text { activity }(\%)\end{array}$ \\
\hline $\begin{array}{l}\text { 1) Cell sonicate after centrifugation at } 4500 \mathrm{~g}^{b} \\
\text { 2) After Amicon treatment (cutoff } 25,000) \text { and }\end{array}$ & 6.1 & 0.0048 & 100 \\
$\begin{array}{l}\text { FPLC on gel column } \\
\text { 3) After concentration on Amicon (cutoff } 30,000)^{c} \\
\text { and FPLC on anion exchange column }\end{array}$ & 2.8 & 0.06 \\
4) After phenyl-Sepharose & 0.25 & 0.48 & 26 \\
\hline
\end{tabular}

a The enzyme activity was determined at $30^{\circ} \mathrm{C}$ in $0.1 M$ Tris- $\mathrm{HCl}, \mathrm{pH} 7.0$, with a [pro-2NA] of $0.167 \mathrm{~m} M$.

${ }^{b}$ The cells were obtained from a $100-\mathrm{ml}$ culture.

' Enzymes I and II, obtained after step 3, gave a specific activity of 0.065 and $0.10 \mu \mathrm{mol} \mathrm{min}^{-1} \mathrm{mg}^{-1}$, respectively.

Table 3. Relative rate of the hydrolysis of amino acid 2 NAs by enzymes I, II, and III ${ }^{a}$

\begin{tabular}{lccc}
\hline Substrate & Enzyme I & Enzyme II & Enzyme III \\
\hline Pro-2NA & $100(10)$ & $100(15)$ & 100 \\
BANA & $600(60)$ & $1(1)$ & 4 \\
L-Hydroxypro-2NA & $10(2)$ & $1(1)$ & 2 \\
L-Pyrrolidonyl-2NA & $6(1)$ & $6(2)$ & 2 \\
L-Threonyl-2NA & $15(2)$ & $5(1)$ & 1 \\
L- $\alpha$-Aspartyl-2NA & $0(0)$ & $3(1)$ & 1 \\
L- $y$-Glutamyl-2NA & $3(0.5)$ & $3(0.5)$ & 0.5 \\
\hline
\end{tabular}

a The reactions were performed in $0.1 M$ Tris- $\mathrm{HCl}$ buffer, $\mathrm{pH} 7.5$ $([\mathrm{S}]=0.167 \mathrm{mM})$. The rate of the hydrolysis of pro-2NA by each enzyme is marked as 100 , and the others are given as relative values. The values in parentheses give the relative rates for enzymes $I$ and II when the hydrolysis of pro-2NA by enzyme III is marked as 100 .

tyrosyl residues for enzyme activity, although these reagents may react with several other groups, including imidazole [16]. EEDQ $(5 \mathrm{mM})$, tested in 0.1 $M$ phosphate buffer, pH 6.0, caused a complete loss of enzyme III activity in $60 \mathrm{~min}$ at $40^{\circ} \mathrm{C}$. These conditions were previously used to study the essentiality of carboxyl groups for enzyme activity [13].

Michaelis-Menten constant. The three plotting methods gave for enzyme III a $\mathrm{K}_{\mathrm{m}}$ value of $0.152 \pm$ $0.015 \mathrm{~m} M(n=6)$ in the hydrolysis of pro-2NA in $0.1 M$ Tris- $\mathrm{HCl}$ buffer, $\mathrm{pH} 7.0\left(30^{\circ} \mathrm{C}\right)$. At $[\mathrm{S}]=$ $0.008-0.333 \mathrm{~m} M$, the reaction followed normal Michaelis-Menten kinetics with no significant substrate inhibition.

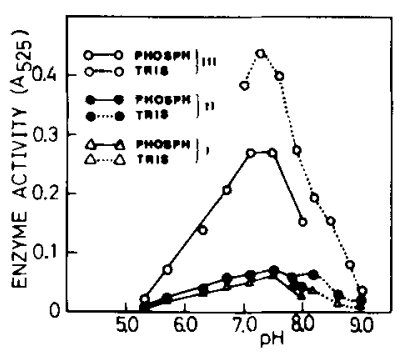

Fig. 2. Effect of $\mathrm{pH}$ on the rate of the hydrolysis of pro-2NA by enzymes 1 , II, and III in $0.1 M$ Tris- $\mathrm{HCl}$ buffer and $0.1 \mathrm{M}$ phosphate buffer. $[$ pro-2NA] $=0.167 \mathrm{~m} M$.

\section{Discussion}

The overall substrate specificity of the sonicates of $T$. denticola toward aminoacyl-2-NAs can be considered exceptional. Substrates that usually are readily hydrolyzed by crude bacterial preparations at a high rate, i.e., $N$-L-leucyl-2NA, $N$-L-alanyl2NA, etc., were hydrolyzed by the present $T$. denticola enzymes at a surprisingly low rate compared with the rate of the hydrolysis of pro-2NA. For example, lactobacilli, streptococci, and other organisms displayed high aminopeptidase activity toward various aminoacyl-2NAs [12]. Treponema denticola ATCC 35405 appeared to be a good producer of iminopeptidase activity, and this enzyme activity can be claimed to be characteristic of this organism. The biological significance of $T$. denticola iminopeptidases may be related to the nutritional requirements of the organism or its ability to protect 
itself against salivary and crevicular immunoglobulins. In both cases it is important to consider the fact that collagen, the hinge region of immunoglobulins, and various salivary peptides are rich in proline. Treponema denticola has been shown in this laboratory to produce a collagenolytic enzyme [18]. It is possible that the iminopeptidases and the collagenolytic enzymes of $T$. denticola act concertedly on some of the biomolecules mentioned above. The importance of iminopeptidases in oral biology was exemplified in a recent study that demonstrated the presence of this enzyme activity in several clinical isolates of $T$. denticola [18].

The modification studies of enzyme III were aimed at the elucidation of the nature of the enzyme to facilitate its classification. It can be concluded that the modification of this enzyme with DEP, TNM, and DSA resulted in effective inactivation. Under the conditions involved, DEP has been regarded as a suitable probe for active histidyl residues, although tyrosyl and lysyl residues, for example, may also react with this reagent [16]. DSA and TNM were used to explore the possible involvement of tyrosyl residues, although particularly the former reagent also reacts with other groups [16]. Both reagents effectively inactivated the enzyme. Combined, these modification studies suggest that the activity of enzyme III may depend on tyrosyl residues. The EEDQ studies may be easier to interpret chemically, because this reagent is relatively specific to enzyme carboxyl groups [13]. The relatively rapid inactivation of enzyme III by EEDQ at $40^{\circ} \mathrm{C}$ suggests that the activity of this enzyme may depend on active carboxyl groups. Further studies with various carbodiimides, Woodward Reagent $\mathrm{K}$, and other modifiers are needed for more final conclusions.

Inhibition of enzyme III by pCMB and the almost total recovery of enzyme activity by DTT speaks for the involvement of an active $\mathrm{SH}$ group in the activity of the enzyme. The modification, inhibition, and specificity studies suggest that enzyme III is a proline iminopeptidase that is highly specific toward pro-2NA. The enzyme may not be classified as a metalloenzyme, but it most likely contains at least one active sufhydryl group, an active carboxyl group, and an active tyrosyl (or histidyl) group as well. Because PMSF, a reagent for active serine residues, caused a marginal $25 \%-27 \%$ inhibition only, the dominant iminopeptidase of this organism may at this stage be called a sulfhydryl peptidase. Other studies have shown that $T$. denticola pos- sesses a distinctive BAPNA-hydrolyzing enzyme which apparently does not degrade proteins [20]. The presence of this enzyme plus the iminopeptidases described here suggest that these peptidases may be necessary for the nutrition of $T$. denticola in dental plaque. Basic amino acids and imino acids would be present in collagen fragments that could exit from the tissue in the gingival crevicular fluid. When periodontal disease is present, there is increased breakdown of collagen in the gingival tissue. These degradation products could provide the necessary nutrients for the increased proteolysis of spirochetes that are characteristic of periodontal disease [11].

\section{ACKNOWLEDGMENT}

This study was supported by NIDR grant DE02731-19.

\section{Literature Cited}

1. Armitage GC, Dickinson WR, Jenderseck RS, Levine SM, Chambers DW (1982) Relationship between the percentage of subgingival spirochetes and the severity of periodontal disease. J Periodontol 53:550-556

2. Bradford MM (1976) A rapid and sensitive method for the quantitation of microgram quantities of protein utilizing the principle of protein-dye binding. Anal Biochem 72:248-254

3. Canale-Parola E (1977) Physiology and evolution of spirochetes. Bacteriol Rev 41:181-204

4. Chavira R Jr, Burnett TJ, Hageman JH (1984) Assaying proteinase with azocoll. Anal Biochem 136:446-450

5. Cheng S-L, Chan ECS (1983) The routine isolation, growth and maintenance of the intermediate-size anaerobic oral spirochetes from periodontal pockets. J Periodontol Res $18: 36-368$

6. Church FC, Porter DH, Catignani GL, Swaisgood HE (1985) An $o$-phthaldehyde spectrophotometric assay for proteinases. Anal Biochem 146:343-348

7. Erlanger BF, Kokowsky N, Cohen W (1961) The preparation and properties of two new chromogenic substrates of trypsin. Arch Biochem Biophys 95:271-278

8. Reihn N-E (1986) Enzyme activities from eight small-sized oral spirochetes. Scand J Dent Res 94:132-140

9. Listgarten MA, Levin S (1981) Positive correlation between proportions of subgingival spirochetes and motile bacteria and susceptibility of human subjects to periodontal deterioration. J Clin Periodontol 8:122-138

10. Loesche WJ, Laughon BB (1982) Role of spirochetes in periodontal disease. In: Genco RJ, Mergenhagen SE (eds) Hostparasite interactions in periodontal disease. Washington DC: American Society of Microbiology, pp 62-75

11. Loesche WJ, Syed SA, Schmidt E, Morrison EC (1985) Bacterial profiles of subgingival plaques in periodontitis. J Periodontol 56:447-456

12. Mäkinen KK (1969) The proline iminopeptidases of the human oral cavity. Acta Chem Scand 23:1409-1438

13. Mäkinen KK (1982) Evidence for an active site carboxyl 
group in bovine milk lactoperoxidase. Biochem Int 5:375380

14. Mäkinen KK, Mäkinen P-L (1971) Effect of sodium chloride on substrate constant and maximum velocity in the enzymatic hydrolysis of $N$-L-aminoacyl-2-naphthylamines and $N$ L-aminoacyl-p-nitroanilines. Acta Chem Scand 25:969-975

15. Mäkinen KK, Mäkinen P-L (1978) Purification and characterization of two human erythrocyte arylamidases preferentially hydrolysing $N$-terminal arginine or lysine residues. Biochem J 175:1051-1067

16. Mäkinen KK, Mäkinen P-L, Wilkes SH, Bayliss SH, Prescott JM (1982) Chemical modification of Aeromonas aminopeptidase: evidence for the involvement of tyrosyl and carboxyl groups in the activity of the enzyme. Eur $\mathrm{J}$ Biochem 128:157-265

17. Mäkinen KK, Söderling E, Virtanen KK, Kotiranta J (1985) Partial purification and characterization of arylamidases from human palatine secretions. Arch Oral Biol 7:513-517

18. Mäkinen KK, Syed SA, Mäkinen P-L, Loesche WJ (1986) Benzoylarginine peptidase and iminopeptidase profiles of Treponema denticola strains isolated from the human periodontal pocket. Curr Microbiol 14:85-89

19. Moore GL (1969) Use of azo-dye-bound collagen to measure reaction velocities of proteolytic enzymes. Anal Biochem $32: 122-127$

20. Ohta K, Mäkinen KK, Loesche WJ (1986) Purification and characterization of an enzyme from Treponema denticola capable of hydrolyzing synthetic trypsin substrates. Infect Immun 53:213-220

21. Olsen I (1984) Attachment of Treponema denticola to cultured human epithelial cells. Scand J Dent Res 92:55-63

22. Sachar L, Winter KK, Sicher N, Frankel S (1955) Photometric method for estimation of elastase activity. Proc Soc Exp Biol Med 90:323-326

23. Seppä HE, Järvinen M (1978) Rat skin main neutral protease: purification and properties. J Invest Dermatol 70:84-89

24. Takahashi T, Asari K, Sato N, Yamaya S, Sugahara T (1985) Purification and properties of an aminopeptidase from Treponema phagedenis (Reiter strain). Curr Microbiol 12:283-288

25. Uitto VJ, Chan ECS, Chin Quee T (1986) Initial characterization of neutral proteinases from oral spirochetes. J Periodontol Res 21:95-100

26. Wünsch E, Heidrich HG (1963) Quantitative Bestimmung der Kollagenase. Z Physiol Chem 333:149-151 